\title{
Meiothermus cateniformans sp. nov., a slightly thermophilic species from north-eastern China
}

Correspondence
Min Wu
wumin@zju.edu.cn

\author{
Xin-Oi Zhang, ${ }^{1}$ Wen-Jie Zhang, ${ }^{1}$ Bo-Ping Wei, ${ }^{2}$ Xue-Wei Xu, ${ }^{3,4}$ \\ $\mathrm{Xu}$-Fen $\mathrm{Zhu}^{1}$ and $\mathrm{Min} \mathrm{Wu}^{1}$ \\ ${ }^{1}$ College of Life Sciences, Zhejiang University, Hangzhou 310058, PR China \\ ${ }^{2}$ Environmental Monitoring Station of Akesu Area, Akesu 843000, PR China \\ ${ }^{3}$ Laboratory of Marine Ecosystem and Biogeochemistry, State Oceanic Administration, Hangzhou \\ 310012, PR China \\ ${ }^{4}$ Second Institute of Oceanography, State Oceanic Administration, Hangzhou 310012, PR China
}

On the basis of phylogenetic, phenotypic and chemotaxonomic distinctiveness, the genus Meiothermus was created to accommodate some members of the genus Thermus (Nobre et al., 1996). Six species of the genus Meiothermus have validly published names: Meiothermus ruber (Loginova et al., 1984), M. silvanus and M. chliarophilus (Tenreiro et al., 1995), M. cerbereus (Chung et al., 1997), M. taiwanensis (Chen et al., 2002b) and M. timidus (Pires et al., 2005). A strain that shares 99.7 and $98.6 \% 16 \mathrm{~S}$ rRNA gene sequence similarity with the type strains of $M$. ruber and $M$. taiwanensis has been assigned to 'Meiothermus rosaceus' (Chen et al., 2002a), but this name has not been validly published.

In natural environments, Meiothermus strains have been found exclusively in thermal limnetic systems, predominantly in terrestrial hot springs (Pires et al., 2005; da Costa et al., 2006). Strains of M. ruber have been isolated from geothermal areas worldwide, even from man-made thermal environments, while the distribution of the other five Meiothermus species seems to be regional (Nobre \& da

The GenBank/EMBL/DDBJ accession numbers for the 16S rRNA gene sequences of strains LY1 $1^{\top}$ and L462 are EU247891 and EU247890, respectively.
Costa, 2001): for example, strains of $M$. chliarophilus and $M$. taiwanensis have been isolated only from hot springs in central Portugal and Taiwan, respectively. In this study, two strains, $\mathrm{LY} 1^{\mathrm{T}}$ and $\mathrm{L} 462$, were isolated from a hot spring located in the Qianshan area, Anshan, north-eastern China, where Meiothermus strains have never been reported before.

Enrichment and isolation were performed with Thermus medium (da Costa et al., 2006). Water samples were filtered through membrane filters $(0.22 \mu \mathrm{m})$, which were subsequently put into $50 \mathrm{ml}$ flasks containing $20 \mathrm{ml}$ Thermus medium. The preparations were incubated in a rotary waterbath shaker at $55{ }^{\circ} \mathrm{C}$ and 120 r.p.m. for 3 days. Turbid cultures were serially diluted and spread onto Thermus agar plates, which were then incubated at $55{ }^{\circ} \mathrm{C}$ until obvious colonies formed. Distinctive colonies were picked and purified at least five times before being preserved by freeze-drying. Purity of the isolates was verified by morphological examination of colonies and cells.

Cell morphology and motility were examined by optical microscopy (BX40; Olympus) and transmission electron microscopy (JEM-1230; JEOL). The temperature and $\mathrm{pH}$ ranges for growth were examined as described by Chung et al. 
(1997) except that different buffers were used: MES (pH 5.06.5), MOPSO (pH 6.5-7.5), Tricine ( $\mathrm{pH} 7.5-9.0)$ and CAPSO (pH 9.0-10.5).

Single-carbon-source assimilation tests were performed at $55{ }^{\circ} \mathrm{C}$ for 7 days as specified by Chung et al. (1997). Other physiological and biochemical characteristics were examined as described by Hudson et al. (1986), Manaia \& da Costa (1991) and Chung et al. (1997) on Thermus agar plates or in Thermus medium at $55{ }^{\circ} \mathrm{C}$ for 4 days.

Cultures for polar lipid and lipoquinone analysis were incubated up to the exponential phase in $300 \mathrm{ml}$ flasks containing $100 \mathrm{ml}$ Thermus medium at $55{ }^{\circ} \mathrm{C}$ and 100 r.p.m. in a rotary water-bath shaker. Cells were collected and washed by centrifugation. Lipid extraction was carried out as described by Tindall (1991). Individual polar lipids were separated by one-dimensional TLC on silica gel $60 \mathrm{~F}_{254}$ plates (Merck) as described by Chung et al. (1997). Lipoquinones were extracted from freeze-dried cells and purified as described by Tindall (1989). Prepared lipoquinones were analysed with an Agilent 1200 HPLC equipped with a ZORBAX Eclipse XDB-C18 column $(150 \times 4.6 \mathrm{~mm}$, particle size $5 \mu \mathrm{m}$; Agilent) (Chung et al., 1997).

Cultures for fatty acid analysis were prepared as specified previously (Chung et al., 1997). Fatty acid methyl esters (FAMEs) were obtained from freeze-dried cells as described by Kuykendall et al. (1988) except that several drops of saturated $\mathrm{NaCl}$ solution were added together with $0.3 \mathrm{M}$ $\mathrm{NaOH}$ at the final step of extraction. Identification and quantification of the FAMEs, as well as numerical analysis of fatty acid profiles, were performed automatically by using the Sherlock Microbial Identification System with the standard MIS Library Generation software (MIDI, Inc.).

Genomic DNA used in PCR amplification was extracted as described by Rainey et al. (1996). The 16S rRNA gene was amplified with primers 27F (5'-AGAGTTTGATCCTGGCTCAG- $\left.3^{\prime}\right)$ and 1492R (5'-ACGGYTACCTTGTTACGACTT- ${ }^{\prime}$ ). Sequences comprising unambiguous nucleotides between positions 28 and 1491 (Brosius et al., 1978) were compared with all closely related sequences with the EzTaxon service (Chun et al., 2007). Multiple sequence alignment was performed with CLUSTAL $\mathrm{W}$ version 1.8 (Thompson et al., 1994). The method of Jukes \& Cantor (1969) was used to calculate evolutionary distances. Phylogenetic trees were constructed by the neighbourjoining method (Saitou \& Nei, 1987) with MEGA4 (Tamura et al., 2007) and by the maximum-parsimony method (Fitch, 1971) with PHYLIP version 3.6 (Felsenstein, 1993).

The DNA $\mathrm{G}+\mathrm{C}$ content was determined by the thermal denaturation temperature $\left(T_{\mathrm{m}}\right)$ method (Marmur \& Doty, 1962) with Escherichia coli K-12 DNA as the calibration standard. DNA-DNA hybridization was performed with the thermal denaturation and renaturation method described by De Ley et al. (1970) and modified by Huß et al. (1983) using a Beckman DU800 spectrophotometer.
Following enrichment and isolation, six pigmented strains were recovered from a hot spring located in the Qianshan area in north-eastern China. On the basis of 16S rRNA gene sequence similarity, one strain, which was yellowpigmented, was found to be affiliated with Thermus igniterrae ( $100 \%$ similarity to the type strain) and three were members of $M$. ruber (99.8-100\% similarity to the type strain). The remaining two, strains $\mathrm{LY}^{\mathrm{T}}$ and $\mathrm{L} 462$, were considered to represent a potential novel Meiothermus species and therefore were selected for further study.

Strains $L Y 1^{\mathrm{T}}$ and $\mathrm{L} 462$ were rose- and orange-pigmented, respectively. Cells were short, non-motile and nonsporulating rods. After the end of the exponential phase, cells tended to occur in chains (Fig. 1). Gram-staining was negative. Thin-section electron micrographs also showed a typical Gram-negative cell wall structure, which consisted of a thin, electron-dense inner layer representing the peptidoglycan and a thick outer layer that connected with the former (not shown). Both of the new isolates grew at $30-66{ }^{\circ} \mathrm{C}$ and $\mathrm{pH} 5.5-10.0$, with optimum growth at 55$60{ }^{\circ} \mathrm{C}$ and $\mathrm{pH} 8.0-8.5$. Strain $\mathrm{LY}^{\mathrm{T}}$ grew well at $67{ }^{\circ} \mathrm{C}$; however, no growth occurred at $68{ }^{\circ} \mathrm{C}$.

Detailed results of physiological and biochemical examination are summarized in Table 1 . Strain $\mathrm{LY}^{\mathrm{T}}$ was different from the three reference strains and even from strain L462 in physiological and biochemical characteristics. Among the five tested strains, $L Y 1^{\mathrm{T}}$ was the only strain that could not hydrolyse casein or assimilate sucrose, lactose, trehalose and

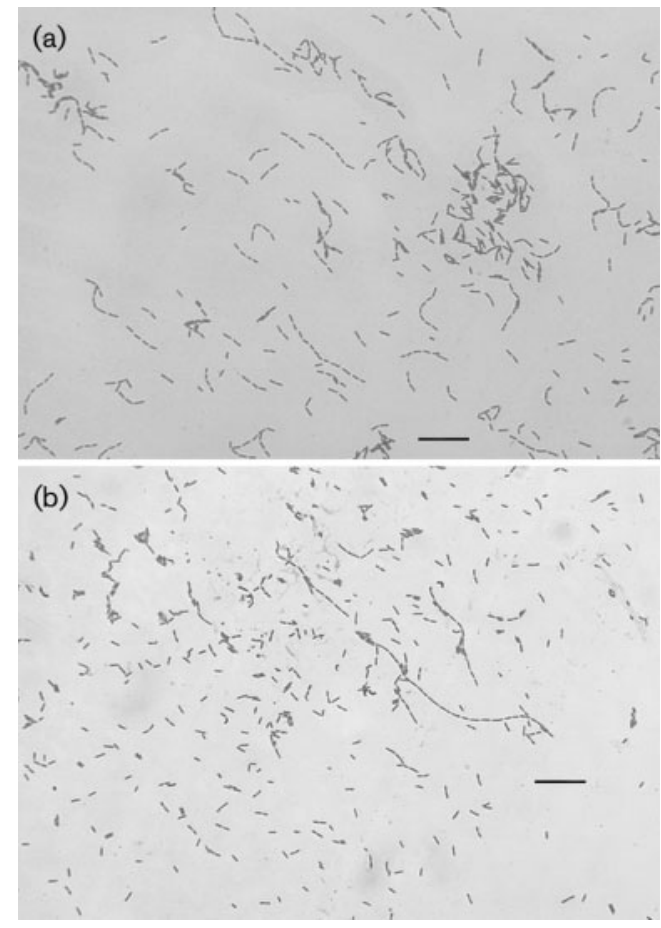

Fig. 1. Cell morphology of strains $L Y 1^{\top}$ (a) and $L 462$ (b) grown in Thermus medium at $55^{\circ} \mathrm{C}$ and $\mathrm{pH}$ 8.2. Bars, $10 \mu \mathrm{m}$. 
Table 1. Phenotypic and genotypic characteristics of the novel isolates and the type strains of related Meiothermus species

Strains: 1, LY1 ${ }^{\mathrm{T}}$; 2, L462; 3, M. ruber DSM $1279^{\mathrm{T}} ; 4$, M. taiwanensis DSM $14542^{\mathrm{T}} ; 5$, M. cerbereus DSM $11376^{\mathrm{T}}$. Data were taken from this study. All strains produced $\beta$-galactosidase, hydrolysed aesculin, DNA and gelatin and utilized L-arginine, L-asparagine, D-fructose, D-galactose, D-glucose, maltose, D-mannose, L-proline and pyruvate. None of the strains hydrolysed starch or xylan or utilized L-arabinose, citrate, raffinose, L-rhamnose or ribitol. +, Positive; w, weakly positive; -, negative.

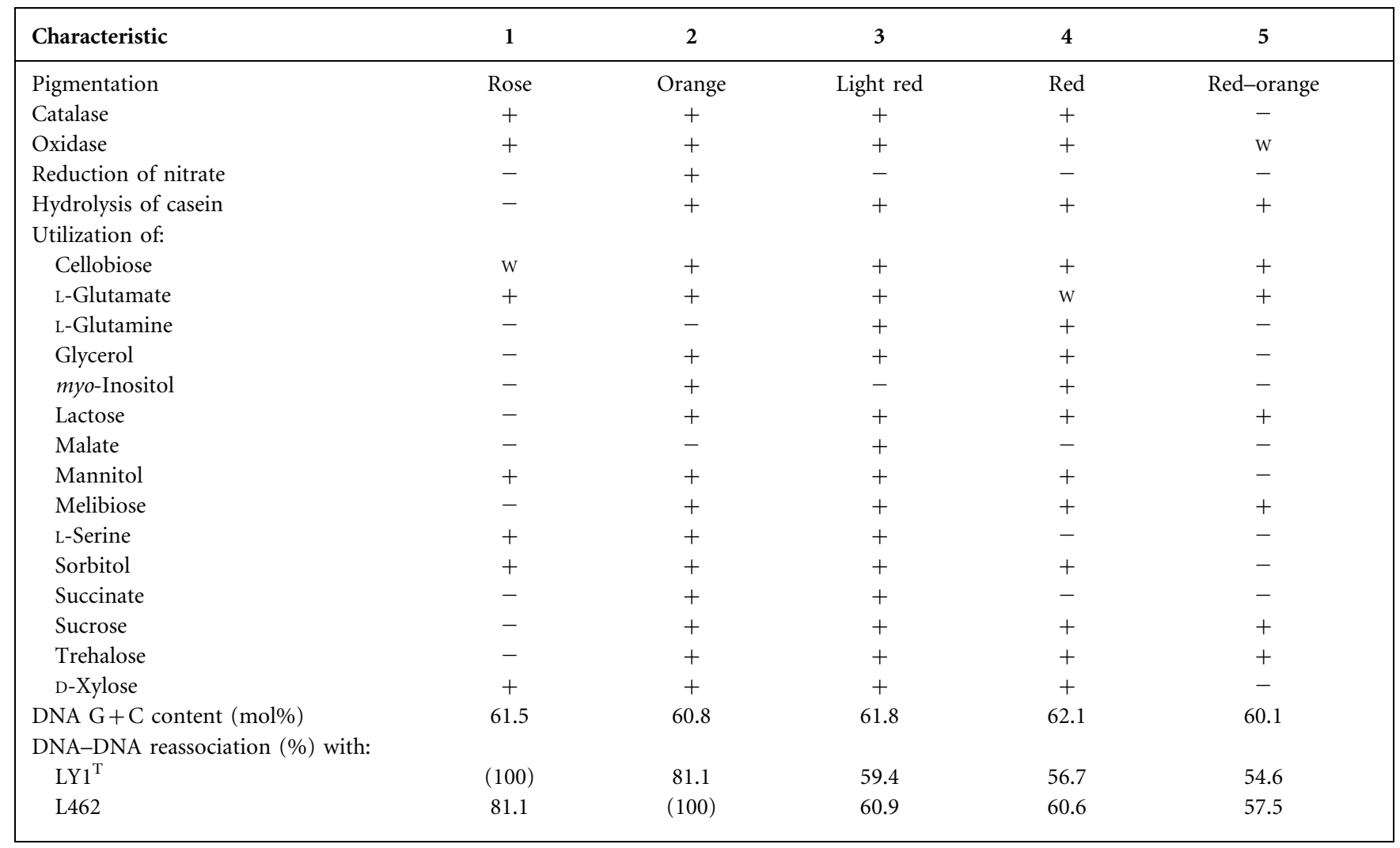

melibiose. Strain L462 was the only strain that could reduce nitrate to nitrite and was more similar to M. ruber DSM $1279^{\mathrm{T}}$ and $M$. taiwanensis DSM $14542^{\mathrm{T}}$ than to strain $\mathrm{LY}^{\mathrm{T}}$.

Polar lipids of strains $\mathrm{LY}^{\mathrm{T}}$ and L462 were composed of one prominent phospholipid and two prominent glycolipids (not shown), which is the typical pattern of the genus Meiothermus. Menaquinone 8 (MK-8) was the predominant respiratory lipoquinone of the isolates, as reported for all other members of genus Meiothermus. The fatty acid compositions of strains $\mathrm{LY}^{\mathrm{T}}$ and $\mathrm{L} 462$ and other related Meiothermus strains are shown in Table 2. For all tested strains, iso- and anteiso-branched $\mathrm{C}_{15: 0}$ and $\mathrm{C}_{17: 0}$ dominated the fatty acid composition, and iso-branched 2-hydroxy fatty acids were present in moderate amounts, which is another common chemotaxonomic characteristic of the genus Meiothermus (Nobre \& da Costa, 2001; da Costa et al., 2006). Nevertheless, anteiso- $C_{17: 0}$ was present in larger amounts in strains $\mathrm{LY}^{\mathrm{T}}$ and L462 than in the three reference strains.

Almost-complete 16S rRNA gene sequences comprising 1455 nucleotides were determined for strains $\mathrm{LY}^{\mathrm{T}}$ and $\mathrm{L} 462$. Similarity analysis based on these and other sequences revealed that the two strains both belonged to genus
Meiothermus. The 16S rRNA gene sequences of the isolates were identical and showed highest sequence similarity with M. ruber ATCC $35948^{\mathrm{T}}$, M. taiwanensis WR- $30^{\mathrm{T}}$ and $M$. cerbereus $\mathrm{GY}^{\mathrm{T}}{ }^{\mathrm{T}}(98.4,98.4$ and $97.1 \%$, respectively). Although these values were appreciably high, it is known that the three species of the $M$. ruber clade are closely related to each other (97.4-98.7\% similarity; Chen et al., 2002b; Chung et al., 1997). Sequence similarity of strains $\mathrm{LY}^{\mathrm{T}}$ and L462 to the other Meiothermus species was lower (89.1-91.0\%) and was comparable to the similarity between species of the M. ruber clade and other Meiothermus species (88.4-91.4 \%; Pires et al., 2005; da Costa et al., 2006). In the phylogenetic analysis (Fig. 2), strains $\mathrm{LY} 1^{\mathrm{T}}$ and L462 formed a sister lineage next to the $M$. ruber clade with a high bootstrap value and clearly represented a novel species within the genus Meiothermus. As strains $\mathrm{LY}^{\mathrm{T}}$ and L462 had comparably high sequence similarity with members of the $M$. ruber clade, they were considered to represent a new member of this cluster that diverged early.

The DNA G $+\mathrm{C}$ contents of strains $\mathrm{LY}^{\mathrm{T}}$ and $\mathrm{L} 462$ were 61.5 and $60.8 \mathrm{~mol} \%\left(T_{\mathrm{m}}\right)$, respectively. DNA-DNA reassociation values between the two isolates and $M$. ruber DSM $1279^{\mathrm{T}}, M$. taiwanensis DSM $14542^{\mathrm{T}}$ and M. cerbereus DSM $11376^{\mathrm{T}}$ are shown in Table 1. Strains LY1 ${ }^{\mathrm{T}}$ and L462 
Table 2. Fatty acid compositions of the novel isolates and the type strains of related Meiothermus species

Strains: $1, \mathrm{LY}^{\mathrm{T}}$; 2, L462; 3, M. ruber DSM $1279^{\mathrm{T}}$; 4, M. taiwanensis DSM $14542^{\mathrm{T}} ; 5$, M. cerbereus DSM $11376^{\mathrm{T}}$. Data were taken from this study. Thiosulfate was not added for the cultivation of M. cerbereus DSM $11376^{\mathrm{T}}$. Values are percentages of total fatty acids. Fatty acids amounting to less than $0.5 \%$ in all strains are omitted; - , not detected $(<0.5 \%)$.

\begin{tabular}{|c|c|c|c|c|c|}
\hline Fatty acid & 1 & 2 & 3 & 4 & 5 \\
\hline iso- $\mathrm{C}_{13: 0}$ & - & - & - & 0.5 & 0.8 \\
\hline iso- $\mathrm{C}_{13: 0} 3-\mathrm{OH}$ & 1.2 & 1.0 & 0.8 & 1.4 & - \\
\hline iso- $\mathrm{C}_{14: 0}$ & 0.9 & 0.5 & - & - & 1.9 \\
\hline $\mathrm{C}_{15: 0}$ & 1.9 & 1.3 & 0.9 & 1.9 & 1.4 \\
\hline iso- $\mathrm{C}_{15: 0}$ & 28.9 & 30.2 & 30.9 & 37.2 & 34.7 \\
\hline anteiso- $\mathrm{C}_{15: 0}$ & 6.4 & 9.8 & 1.9 & 1.9 & 10.1 \\
\hline iso- $\mathrm{C}_{15: 0} 3-\mathrm{OH}$ & - & - & - & - & 0.8 \\
\hline iso- $\mathrm{C}_{15: 1} \mathrm{~F}$ & - & - & 1.3 & - & 2.7 \\
\hline$C_{16: 0}$ & 5.0 & 4.5 & 5.1 & 3.5 & 4.8 \\
\hline iso- $\mathrm{C}_{16: 0}$ & 5.4 & 2.8 & 1.5 & 2.7 & 4.6 \\
\hline $\mathrm{C}_{16: 0} 2-\mathrm{OH}$ & 0.5 & 0.6 & 0.8 & 0.7 & 1.0 \\
\hline $\mathrm{C}_{17: 0}$ & 3.0 & 1.4 & 0.9 & 2.8 & - \\
\hline iso- $\mathrm{C}_{17: 0}$ & 27.6 & 21.8 & 26.9 & 29.9 & 9.5 \\
\hline anteiso- $\mathrm{C}_{17: 0}$ & 8.8 & 11.0 & 3.0 & 2.7 & 4.6 \\
\hline $\mathrm{C}_{17: 0} 2-\mathrm{OH}$ & 0.5 & 0.5 & - & 0.5 & 0.9 \\
\hline iso- $\mathrm{C}_{17: 0} 2-\mathrm{OH}$ & 4.5 & 7.5 & 10.8 & 9.3 & 3.5 \\
\hline iso- $\mathrm{C}_{17: 0} 3-\mathrm{OH}$ & 0.7 & 0.7 & 0.8 & 0.5 & 3.6 \\
\hline $\mathrm{C}_{17: 1} \omega 6 c$ & - & - & - & - & 0.6 \\
\hline $\mathrm{C}_{17: 1} \omega 8 c$ & - & - & 0.5 & - & 0.5 \\
\hline iso- $\mathrm{C}_{17: 1} \omega 9 c$ & - & 0.7 & 6.6 & 0.9 & 5.2 \\
\hline anteiso- $\mathrm{C}_{17: 1} \omega 9 c$ & - & - & - & - & 0.8 \\
\hline iso- $\mathrm{C}_{18: 0}$ & 0.6 & - & - & - & - \\
\hline iso- $\mathrm{C}_{18: 0}$ diol & 1.0 & 0.7 & 1.0 & 1.7 & - \\
\hline iso- $\mathrm{C}_{19: 0}$ & 0.7 & - & - & 0.6 & - \\
\hline
\end{tabular}

had high DNA-DNA reassociation values with each other, which indicated that they represented the same species even though these two strains had obvious differences in physiological and biochemical characteristics. DNA-DNA reassociation between strain $\mathrm{LY}^{\mathrm{T}}$ and the reference strains was $54.6-59.4 \%$, while that between strain L462 and the reference strains was $57.5-60.9 \%$. These data together support the conclusion from the phylogenetic analysis that the isolates represent a novel species of genus Meiothermus.
A number of phenotypic differences could be found between the new isolates and the members of the M. ruber group. For strain $\mathrm{LY} 1^{\mathrm{T}}$, its inability to hydrolyse casein and to utilize melibiose, trehalose, sucrose and lactose clearly differentiate it from the M. ruber group. For strain L462, although it was more similar to M. ruber DSM $1279^{\mathrm{T}}$ and M. taiwanensis DSM $14542^{\mathrm{T}}$ than to strain $\mathrm{LY}^{\mathrm{T}}$ in physiological and biochemical characteristics, phenotypic differences, especially the ability to reduce nitrate, distinguish it from the M. ruber group. The major distinguishing chemotaxonomic characteristic was the relatively large amount of anteiso- $\mathrm{C}_{17: 0}$ in strains $\mathrm{LY}^{\mathrm{T}}$ and $\mathrm{L} 462$.

On the basis of the genotypic and phenotypic characteristics described above, strains $\mathrm{LY}^{\mathrm{T}}$ and $\mathrm{L} 462$ are proposed to represent a novel species of genus Meiothermus, with the name Meiothermus cateniformans sp. nov.

\section{Description of Meiothermus cateniformans sp. nov.}

Meiothermus cateniformans (ca.te.ni.for'mans. L. n. catena chain; L. part. adj. formans forming, fashioning; N.L. part. adj. cateniformans chain-forming, referring to the fact that cells occur in chains after the end of the exponential growth phase).

Cells are non-motile, non-sporulating, short rods, about $0.5 \mu \mathrm{m}$ wide and $1.0-2.5 \mu \mathrm{m}$ long, and form chains after exponential growth. Gram-negative. After growth on Thermus agar for $72 \mathrm{~h}$ at $55{ }^{\circ} \mathrm{C}$, colonies of strain LY $1^{\mathrm{T}}$ are rose-pigmented and 3-4 $\mathrm{mm}$ in diameter while those of strain L462 are orange. Optimal growth occurs at $55-60{ }^{\circ} \mathrm{C}$ and $\mathrm{pH} 8.0-8.5$. The $\mathrm{pH}$ range for growth is $\mathrm{pH}$ 5.5-10.0. No growth occurs below $30{ }^{\circ} \mathrm{C}$. The maximum growth temperature of strain $\mathrm{LY}^{\mathrm{T}}$ is $67^{\circ} \mathrm{C}$ while that of strain L462 is $66^{\circ} \mathrm{C}$. Aerobic and heterotrophic. Catalase-, oxidase- and $\beta$-galactosidase-positive. Aesculin, DNA and gelatin are hydrolysed. Starch and xylan are not degraded. Casein is not hydrolysed by the type strain. Nitrate is reduced by strain L462. The following substrates are utilized: L-arginine, L-asparagine, cellobiose, D-fructose, D-galactose, D-glucose, L-glutamate, maltose, mannitol, Dmannose, L-proline, pyruvate, L-serine, sorbitol and Dxylose. The following compounds are not utilized by the type strain: L-arabinose, citrate, L-glutamine, glycerol, myoinositol, lactose, malate, melibiose, raffinose, L-rhamnose,

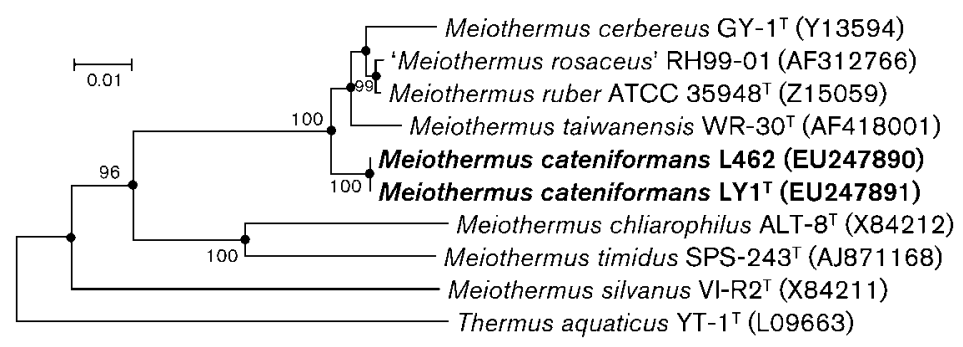

Fig. 2. Neighbour-joining tree based on $16 \mathrm{~S}$ rRNA gene sequences, showing the phylogenetic relationships of the novel isolates and related taxa. Bootstrap values ( $>50 \%$ ) based on 1000 replicates are shown as percentages at branch nodes. Filled circles indicate that the corresponding nodes were also recovered in the maximum-parsimony tree. Bar, 0.01 substitutions per nucleotide position. 
ribitol, succinate, sucrose and trehalose. The major fatty acids are iso- and anteiso-branched $\mathrm{C}_{15: 0}$ and $\mathrm{C}_{17: 0}$. Isobranched 2-hydroxy and 3-hydroxy fatty acids are also present. The DNA G $+\mathrm{C}$ content of the type strain $\mathrm{LY} 1^{\mathrm{T}}$ is $61.5 \mathrm{~mol} \%$ and that of $\mathrm{L} 462$ is $60.8 \mathrm{~mol} \%\left(T_{\mathrm{m}}\right)$.

The type strain $\mathrm{LY} 1^{\mathrm{T}}\left(=\right.$ CGMCC $\left.1.6990^{\mathrm{T}}=\mathrm{JCM} 15151^{\mathrm{T}}\right)$ and reference strain L462 (=CGMCC $1.6989=\mathrm{JCM}$ 15150) were isolated from a hot spring located in the Qianshan area, Anshan, north-eastern China.

\section{Acknowledgements}

This work was supported by grants from the Major State Basic Research Development Program of China (973 Program) (2004CB719604-3), the National Natural Science Foundation of China (30670048) and the National High Technology Research and Development Program of China (863 Program) (2007AA021305). We acknowledge Dr Jean P. Euzéby for his valuable advice in naming the novel species. We also appreciate Dr Ya-Fang Tan (Academy of Military Medical Sciences) for fatty acid composition analysis.

\section{References}

Brosius, J., Palmer, M. L., Kennedy, P. J. \& Noller, H. F. (1978). Complete nucleotide sequence of a $16 \mathrm{~S}$ ribosomal RNA gene from Escherichia coli. Proc Natl Acad Sci U S A 75, 4801-4805.

Chen, C. Y., Lin, L. B., Peng, Q., Ben, K. L. \& Zhou, Z. M. (2002a). Meiothermus rosaceus sp. nov. isolated from Tengchong hot spring in Yunnan, China. FEMS Microbiol Lett 216, 263-268.

Chen, M. Y., Lin, G. H., Lin, Y. T. \& Tsay, S. S. (2002b). Meiothermus taiwanensis sp. nov., a novel filamentous, thermophilic species isolated in Taiwan. Int J Syst Evol Microbiol 52, 1647-1654.

Chun, J., Lee, J. H., Jung, Y., Kim, M., Kim, S., Kim, B. K. \& Lim, Y. W. (2007). EzTaxon: a web-based tool for the identification of prokaryotes based on $16 \mathrm{~S}$ ribosomal RNA gene sequences. Int J Syst Evol Microbiol 57, 2259-2261.

Chung, A. P., Rainey, F., Nobre, M. F., Burghardt, J. \& da Costa, M. S. (1997). Meiothermus cerbereus sp. nov., a new slightly thermophilic species with high levels of 3-hydroxy fatty acids. Int J Syst Bacteriol 47, 1225-1230.

da Costa, M. S., Rainey, F. A. \& Nobre, M. F. (2006). The genus Thermus and relatives. In The Prokaryotes: a Handbook on the Biology of Bacteria, 3rd edn, vol. 7, pp. 797-812. Edited by M. Dworkin, S. Falkow, E. Rosenberg, K. H. Schleifer \& E. Stackebrandt. New York: Springer.

De Ley, J., Cattoir, H. \& Reynaerts, A. (1970). The quantitative measurement of DNA hybridization from renaturation rates. Eur $J$ Biochem 12, 133-142.

Felsenstein, J. (1993). PHYLIP (phylogeny inference package) version 3.5.1. Distributed by the author. Department of Genome Sciences, University of Washington, Seattle, USA.

Fitch, W. M. (1971). Toward defining the course of evolution: minimum change for a specific tree topology. Syst Zool 20, 406-416.
Hudson, J. A., Morgan, H. W. \& Daniel, R. M. (1986). A numerical classification of some Thermus isolates. J Gen Microbiol 132, 531-540.

Huß, V. A. R., Festl, H. \& Schleifer, K. H. (1983). Studies on the spectrophotometric determination of DNA hybridization from renaturation rates. Syst Appl Microbiol 4, 184-192.

Jukes, T. H. \& Cantor, C. R. (1969). Evolution of protein molecules. In Mammalian Protein Metabolism, vol. 3, pp. 21-132. Edited by H. N. Munro. New York: Academic Press.

Loginova, L. G., Egorova, L. A., Golovacheva, R. S. \& Seregina, L. M. (1984). Thermus ruber sp. nov., nom. rev. Int J Syst Bacteriol 34, 498499.

Manaia, C. M. \& da Costa, M. S. (1991). Characterization of halotolerant Thermus isolates from shallow marine hot springs on S. Miquel, Azores. J Gen Microbiol 137, 2643-2648.

Marmur, J. \& Doty, P. (1962). Determination of the base composition of deoxyribonucleic acid from its thermal denaturation temperature. J Mol Biol 5, 109-118.

Nobre, M. F. \& da Costa, M. S. (2001). Genus II. Meiothermus. In Bergey's Manual of Systematic Bacteriology, 2nd edn, vol. 1, pp. 414420. Edited by D. R. Boone, R. W. Castenholtz \& G. M. Garrity. New York: Springer.

Nobre, M. F., Trüper, H. G. \& da Costa, M. S. (1996). Transfer of Thermus ruber (Loginova et al. 1984), Thermus silvanus (Tenreiro et al. 1995), and Thermus chliarophilus (Tenreiro et al. 1995) to Meiothermus gen. nov. as Meiothermus ruber comb. nov., Meiothermus silvanus comb. nov., and Meiothermus chliarophilus comb. nov., respectively, and emendation of the genus Thermus. Int $J$ Syst Bacteriol 46, 604-606.

Pires, A. L., Albuquerque, L., Tiago, I., Nobre, M. F., Empadinhas, N., Veríssimo, A. \& da Costa, M. S. (2005). Meiothermus timidus sp. nov., a new slightly thermophilic yellow-pigmented species. FEMS Microbiol Lett 245, 39-45.

Rainey, F. A., Ward-Rainey, N., Kroppenstedt, R. M. \& Stackebrandt, E. (1996). The genus Nocardiopsis represents a phylogenetically coherent taxon and a distinct actinomycete lineage: proposal of Nocardiopsaceae fam. nov. Int J Syst Bacteriol 46, 1088-1092.

Saitou, N. \& Nei, M. (1987). The neighbor-joining method: a new method for reconstructing phylogenetic trees. Mol Biol Evol 4, 406425.

Tamura, K., Dudley, J., Nei, M. \& Kumar, S. (2007). MEGA4: molecular evolutionary genetics analysis (MEGA) software version 4.0. Mol Biol Evol 24, 1596-1599.

Tenreiro, S., Nobre, M. F. \& da Costa, M. S. (1995). Thermus silvanus sp. nov. and Thermus chliarophilus sp. nov., two new species related to Thermus ruber but with lower growth temperatures. Int J Syst Bacteriol 45, 633-639.

Thompson, J. D., Higgins, D. G. \& Gibson, T. J. (1994). Clustal W: improving the sensitivity of progressive multiple sequence alignment through sequence weighting, position-specific gap penalties and weight matrix choice. Nucleic Acids Res 22, 4673-4680.

Tindall, B. J. (1989). Fully saturated menaquinones in the archaebacterium Pyrobaculum islandicum. FEMS Microbiol Lett 60, 251-254.

Tindall, B. J. (1991). Lipid composition of Rhodothermus marinus. FEMS Microbiol Lett 80, 65-68. 